\title{
GAMBARAN DISFUNGSI SEKSUAL, DISABILITAS, DAN KUALITAS HIDUP PADA PASIEN PASCASTROKE
}

\author{
A DESCRIPTION OF SEXUAL DYSFUNCTION, DISABILITY, AND QUALITY \\ OF LIFE OF POST-STROKE PATIENTS \\ Hasanul Arifin, * Alfansuri Kadri, * Yuneldi Anwar*
}

\begin{abstract}
Introduction: Sexual function and disability are post-stroke complications that can affect the long-term quality of life. The problem is being neglected, thus cannot be intervened further. There are simple screenings that can be used to detect the disorder.

Aim: To determine the characteristics of sexual dysfunction, disability and quality of life, and also demographic profile of post stroke patients in Neurology Outpatient Clinic at General Hospital Haji Adam Malik, Medan.

Method: A cross sectional descriptive study on poststroke patients in Neurology Outpatient Clinic of General Hospital Adam Malik, Medan between March and July 2018. Subjects were asked to fill three questionnaires; Changes in Sexual Functioning Questionnaire (CSFQ-14) to assess sexual dysfunction, Stroke-Specific Quality of Life (SS-QoL-12) to assess quality of life, and Barthel Index (BI) and modified Rankin Scale (mRS) to assess disability.

Results: We identified 45 subjects and the mean of age was $60.27+10.12$ years, mostly men (75.6\%) and was suffered from ischemic stroke (95.6\%). Majority of the subjects (93.3\%) were reported of having sexual dysfunction, some have symptoms of disability (35.6\%) and full dependence (44.5\%). The quality of life was relatively better in male, especially in the physical domain.

Discussion: In post stroke population, the prevalence of sexual dysfunction is $93.3 \%$, mostly affected male patients. Majority of the subjects were independent and without significant disability. The quality of life was relatively better in male and the lowest value related to health was the power domain.
\end{abstract}

Keywords: Disability, post-stroke, quality of life, sexual dysfunction

\section{ABSTRAK}

Pendahuluan: Salah satu komplikasi pascastroke adalah gangguan fungsi dan disabilitas seksual yang dapat memengaruhi kualitas hidup jangka panjang. Namun hal ini masih terabaikan, hingga tidak dapat diintervensi lebih lanjut. Terdapat beberapa skrining sederhana yang dapat digunakan untuk mendeteksi gangguan tersebut.

Tujuan: Untuk mengetahui gambaran disfungsi seksual, disabilitas, dan kualitas hidup pada penderita pascastroke di rawat jalan Neurologi RSUP Haji Adam Malik, Medan.

Metode: Penelitian deskriptif dengan studi potong lintang pada pasien pascastroke di Poliklinik Neurologi RSUP Haji Adam Malik, Medan pada bulan Maret-Juli 2018. Subjek diminta mengisi 3 kuesioner, yaitu: Changes in Sexual Functioning Questionnaire (CSFQ-14) untuk menilai perubahan fungsi seksual, Stroke-Specific Quality of Life (SS-QoL-12) untuk menilai kualitas hidup, serta Indeks Barthel (IB) dan modified Rankin Scale (mRS) untuk menilai disabilitas.

Hasil: Didapatkan 45 subjek dengan rerata usia 60,27+10,12 tahun, terutama laki-laki $(75,6 \%)$ dan menderita stroke iskemik (95,6\%). Mayoritas subjek mengalami disfungsi seksual (93,3\%), sebagian memiliki gejala disabilitas (35,6\%) dan ketergantungan penuh (44,5\%). Kualitas hidup relatif lebih baik pada laki-laki dan khususnya pada domain fisik.

Diskusi: Didapatkan prevalensi disfungsi seksual sebanyak 93,3\% pada pasien pascastroke, terutama laki-laki. Mayoritas subjek pada keadaan mandiri dan disabilitas yang tidak signifikan. Gambaran kualitas hidup secara keseluruhan relatif lebih baik pada laki-laki dengan nilai yang berhubungan dengan kesehatan yang relatif paling rendah adalah domain tenaga.

Kata Kunci: Disabilitas, disfungsi seksual, kualitas hidup, pascastroke

\footnotetext{
*Departemen Neurologi FK Universitas Sumatera Utara/RSUP Haji Adam Malik, Medan. Korespondensi: hasanularifin85@gmail. com.

\section{PENDAHULUAN}

Stroke merupakan penyakit yang menjadi perhatian utama dalam kesehatan masyarakat serta penyebab utama mortalitas dan kecacatan di seluruh dunia. Selama 20 tahun terakhir terjadi penurunan

angka kematian akibat stroke di negara maju daripada di negara-negara berkembang, yang berarti meningkatkan beban perawatan pasien pascastroke secara global. ${ }^{1-2}$

Stroke adalah penyebab utama kecacatan yang
} 
didapat pada orang dewasa. ${ }^{3}$ Di Amerika Serikat angka kejadian stroke menurun sekitar $60 \%$ dan menjadi urutan keempat penyebab utama kematian setelah penyakit jantung, keganasan, dan penyakit saluran pernapasan kronis bagian bawah selama 30 tahun terakhir. ${ }^{4}$ Sekitar $60 \%$ kematian akibat stroke terjadi di luar perawatan rumah sakit. ${ }^{5}$

Berdasarkan laporan Riset Kesehatan Dasar 2013, prevalensi stroke di Indonesia berdasarkan diagnosis tenaga kesehatan sebesar 7 per mil dan yang terdiagnosis tenaga kesehatan atau gejala sebesar 12,1 per mil. ${ }^{6}$ Pada 562 pasien stroke di $25 \mathrm{RS}$ di Sumatera Utara, didapatkan mayoritas perempuan $(52,7 \%)$ dengan rerata usia 59 (20-95) tahun. ${ }^{7}$

Stroke telah menjadi penyebab utama disabilitas yang dapat mengganggu fisik, linguistik, fungsi kognitif, dan seksual. Disfungsi seksual dapat memperlihatkan penurunan libido, impotensi, atau ketidakmampuan untuk ejakulasi pada lakilaki atau penurunan libido, lubrikasi vagina yang berkurang, masalah gairah atau disfungsi orgasme pada perempuan. Penderita stroke sering malu mendiskusikan permasalahan hal ini. Kesabaran pasien dan ketidaktahuan dokter menyebabkan pengabaian disfungsi seksual pascastroke, termasuk dalam menentukan mekanisme dan tata laksana yang sesuai. $^{8-9}$

Disfungsi seksual pascastroke cukup umum terjadi dengan prevalensi antara 20 sampai $75 \%$ atau setidaknya pada $70-80 \%$ pasangan. ${ }^{10-11}$ Disfungsi meningkat seiring bertambahnya usia dengan risiko yang sama dengan faktor kesehatan umum, kejiwaan, dan gangguan psikologis, serta kondisi sosialdemografis. Pada laki-laki, disfungsi seksual yang sering terjadi antara lain penurunan libido, disfungsi ereksi, dan masalah ejakulasi.

Disfungsi seksual memengaruhi emosi dan kesejahteraan psikologis pada pascastroke yang bertahan dan berdampak pada kualitas hidup yang berhubungan dengan kesehatan (Health-Related Quality of Life/HRQoL). ${ }^{12}$ Namun, dampak disfungsi seksual pada HRQoL belum banyak dieksplorasi. Padahal fungsi seksual merupakan komponen penting untuk kualitas hidup dan aktivitas kehidupan sehari- hari. Oleh karena itu, dokter spesialis neurologi dan rehabilitasi, termasuk ahli terapi fisik, okupasi, dan wicara, harus memberikan fisioterapi yang ditujukan pada seksualitas pada perawatan pasien pascastroke. Ahli seksolog dan terapis seks harus menjadi bagian yang tidak terpisahkan dari tim rehabilitasi. ${ }^{12-14}$

Pasien pascastroke juga biasanya kehilangan fungsionalitas dalam hal sosial, emosional, fisik, serta dapat timbul gangguan dalam pekerjaan. Adanya tingkat disabilitas global, kelelahan pascastroke, dan depresi berdampak negatif terhadap kualitas hidup. ${ }^{9}$ Perhatian utama untuk penderita stroke adalah memaksimalkan kualitas tersebut, sehingga perlu dilakukan penelitian ini.

\section{TUJUAN}

Untuk mengetahui prevalensi serta gambaran disfungsi seksual, disabilitas, dan kualitas hidup pada penderita pascastroke di RSUP Haji Adam Malik, Medan.

\section{METODE}

Penelitian deskriptif secara potong lintang terhadap pasien pascastroke di Poliklinik Neurologi RSUP Haji Adam Malik, Medan, pada bulan Maret 2018 sampai dengan Juli 2018. Kriteria inklusi adalah semua pasien pascastroke sekurangkurangnya 3 (tiga) bulan sebelumnya, berusia $>18$ tahun, memiliki paling tidak 1 pasangan seksual regular selama minimal 3 bulan sebelum penelitian, bisa berkomunikasi dengan baik, dan setuju untuk ikut serta dalam penelitian. Kriteria eksklusi yaitu pasien yang memiliki riwayat disfungsi seksual sebelum stroke, gangguan jiwa, atau demensia.

Subjek diminta mengisi 3 kuesioner, yaitu: Changes in Sexual Functioning Questionnaire (CSFQ-14) untuk menilai perubahan fungsi seksual, Stroke-Specific Quality of Life (SS-QoL-12) untuk menilai kualitas hidup, serta Indeks Barthel (IB) dan modified Rankin Scale (mRS) untuk menilai disabilitas. Kuesioner CSFQ-14 terdiri dari 14 pertanyaan untuk menilai: kesenangan, hasrat/ frekuensi, hasrat/minat, gairah/rangsangan, dan orgasme/penyelesaian. Skor CSFQ-14 minimal 14 dan maksimal 70. Pada perempuan dinyatakan disfungsi pada nilai $<41$, sedangkan pada laki-laki 
jika nilai skor $<47 .{ }^{12}$

Skor SSQoL terdiri dari 49 pertanyaan yang dikelompokkan menjadi 12 domain. Setiap domain terdiri dari 3 hingga 10 butir nomor dengan nilai minimum 1 (hasil terburuk) dan nilai maksimum 5 (hasil terbaik). Terdapat 12 item yang dikelompokkan menjadi fisik dan psikososial. Skor yang lebih tinggi menunjukkan fungsi yang lebih baik ${ }^{12,15}$ yang dibagi ke dalam lima tingkatan, yaitu sangat buruk $(1,00$ $1,50)$; buruk (1,51-2,50); sedang (2,51-3,50); baik (3,51-4,50); dan unggul $(4,51-5,00) .{ }^{16}$

Skor IB terdiri dari 10 butir nomor dengan total poin bervariasi antara 0 dan 100. Skor (020) menyatakan ketergantungan total, (21-60) ketergantungan berat, (61-90) ketergantungan sedang, dan (91-99) ketergantungan ringan..$^{15,17}$

Skor mRS terdiri dari 5 angka dengan pembagian kategori tingkatan disabilitas berdasarkan mRS dengan skor (0-1) tidak ada gejala atau tidak signifikan disabilitas, (2-3) disabilitas ringan atau sedang, dan (4-5) disabilitas berat. ${ }^{18}$

Kuesioner CSFQ-14 yang telah terbukti memiliki validitas dan reabilitas yang baik. Skala CSFQ-14 memiliki konsistensi internal yang baik, dengan koefisien alpha Cronbach sebesar 0,90 untuk total sampel, 0,91 untuk pria, dan 0,87 untuk perempuan. ${ }^{12,19}$ Alat pengukuran untuk keterbatasan fungsional pada pasien pascastroke adalah Indeks Barthel (IB) dan Skala Rankin yang dimodifikasi (mRS). Skala mRS lebih global dibandingkan dengan IB dan mempunyai reliabilitas dan validitas yang cukup baik. Indeks Barthel memiliki reliabilitas dan validitas yang tinggi, mudah dan cukup sensitif untuk mengukur perubahan fungsi dan keberhasilan rehabilitas. ${ }^{17}$ Skor SSQoL-14 dipakai untuk menilai kualitas hidup yang berhubungan dengan kesehatan. Instrumen SSQoL telah terbukti dapat diterima untuk melakukan pengukuran kualitas hidup pasien pascastroke. ${ }^{12,18}$ Skor CSFQ-14, SSQoL sudah divalidasi dan diterjemahkan dalam bahasa Indonesia di Pusat Bahasa Universitas Sumatera Utara. ${ }^{18,20-21}$ Demikian pula mRS dan IB sudah diterjemahkan dalam Bahasa Indonesia dan telah umum dipakai di institusi lain seluruh dunia.
Data hasil penelitian dianalisis secara statistik menggunakan program SPSS. Dilakukan analisis deskriptif untuk melihat gambaran karakteristik demografi berdasarkan usia, jenis kelamin, lokasi lesi dan riwayat stroke berulang, gambaran disfungsi seksual, tingkat disabilitas, serta kualitas hidup.

\section{HASIL}

Didapatkan 45 subjek (Tabel 1) dengan rerata usia $60,27 \pm 10,12$ tahun, mayoritas laki-laki $(75,6 \%)$ dan menderita stroke iskemik $(95,6 \%)$.

Tabel 1. Gambaran Karakteristik Demografi dan Klinis $(n=45)$

\begin{tabular}{lc}
\hline \multicolumn{1}{c}{ Karakteristik Demografi } & $\mathbf{n}(\%)$ \\
\hline Usia (thn), Rerata \pm SD & $60,27 \pm 0,12$ \\
Jenis Kelamin & \\
- Laki-laki & \\
- Perempuan & $34(75,6)$ \\
Pendidikan & $11(24,4)$ \\
- $<9$ tahun & \\
- >9 tahun & $15(34,3)$ \\
Tipe Stroke & $30(65,7)$ \\
- Stroke iskemik & \\
- Stroke hemoragik & $43(95,6)$ \\
Durasi Pascastroke (bulan), & $2(4,4)$ \\
Rerata \pm SD & $16,29+15,66$ \\
Faktor Risiko Stroke & \\
- Hipertensi & \\
- Diabetes mellitus & \\
- Hiperkolesterol & $42(93,3)$ \\
- Penyakit jantung & $14(31,1)$ \\
- Merokok & $27(60,0)$ \\
Lokasi Lesi & $15(33,3)$ \\
- Hemisfer kanan & $25(55,6)$ \\
- Hemisfer kiri & \\
- Kedua hemisfer & \\
- Tidak ada kelainan & $17(37,8)$ \\
Riwayat Serangan Stroke & $17(37,8)$ \\
- Serangan pertama & $3(17,8)$ \\
- Serangan berulang & $8(6,7)$ \\
\hline
\end{tabular}

Hampir seluruh subjek (Tabel 2) mengalami disfungsi seksual (93,3\%), terutama laki-laki $(78,6 \%)$. Rerata skor fungsi seksual pada laki-laki $(32,53 \pm 7,64)$ lebih tinggi dari pada perempuan $(28,45 \pm 13,04)$, baik dari domain kesenangan, hasrat maupun gairah yang menunjukkan bahwa perempuan memiliki fungsi seksual yang rendah (Tabel 3). 
Tabel 2. Disfungsi Seksual pada Laki-laki dan Perempuan $(n=45)$

\begin{tabular}{|c|c|c|c|}
\hline Variabel & $\begin{array}{c}\text { Laki-laki } \\
\text { n (\%) }\end{array}$ & $\begin{array}{c}\text { Perempuan } \\
\text { n (\%) }\end{array}$ & $\begin{array}{l}\text { Total } \\
\text { n (\%) }\end{array}$ \\
\hline \multicolumn{4}{|c|}{ Disfungsi Seksual } \\
\hline & $33(97,0)$ & $9(8$ & $\begin{array}{c}42 \\
(93,3)\end{array}$ \\
\hline - Tidak & $1(2,9)$ & $2(18,2)$ & $3(6,7)$ \\
\hline
\end{tabular}

Tabel 3. Gambaran Domain Skala Fungsi Seksual pada Laki-laki dan Perempuan $(n=45)$

\begin{tabular}{lcc}
\hline \multicolumn{1}{c}{ Skala Domain } & $\begin{array}{c}\text { Laki-laki } \\
(\mathbf{n}=\mathbf{3 4})\end{array}$ & $\begin{array}{c}\text { Perempuan } \\
(\mathbf{n}=\mathbf{1 1})\end{array}$ \\
\hline Kesenangan & $2,38+1,81$ & $1,91+1,14$ \\
Hasrat/frekuensi & $4,50+4,00$ & $4,00+2,24$ \\
Hasrat/minat & $7,09+2,56$ & $5,27+2,53$ \\
Gairah/rangsangan & $6,47+2,18$ & $5,64+2,94$ \\
Orgasme/penyelesaian & $6,18+2,32$ & $6,64+5,02$ \\
Rerata skor CSFQ-14 & $32,53+7,64$ & $28,45+13,04$ \\
\hline
\end{tabular}

CSFQ: Changes in Sexual Functioning Questionnaire.

Rerata skor IB pada penelitian ini (Tabel 4) adalah $86,89+20,76$ kategori indeks terbanyak adalah mandiri (55,6\%). Kategori disabilitas berdasarkan modified Rankin Scale yang paling banyak adalah disabilitas yang tidak signifikan (64,4\%).

Tabel 4. Gambaran Kategori Disabilitas Subjek $(n=45)$

\begin{tabular}{lc}
\hline \multicolumn{1}{c}{ Kategori Disabilitas } & n (\%) \\
\hline $\begin{array}{l}\text { Indeks Barthel, Rerata } \pm \text { SD } \\
\text { Kategori Indeks Barthel }\end{array}$ & $86,89+20,76$ \\
- Mandiri & \\
- Ketergantungan ringan & $7(55,6)$ \\
- Ketergantungan sedang & $4(8,9)$ \\
- Ketergantungan berat & $9(20,0)$ \\
Kategori Modified Rankin Scale & \\
- Tidak signifikan disabilitas & $29(64,4)$ \\
- Disabilitas ringan-sedang & $13(28,9)$ \\
- Disabilitas berat & $3(6,7)$ \\
\hline
\end{tabular}

Rerata skor total HRQoL adalah $3,41 \pm 0,8$. Kualitas hidup secara keseluruhan relatif lebih tinggi dijumpai pada satu domain 3 (bahasa) dengan rerata 4,01, dan diikuti domain 7, 10, dan 11 (merawat diri, fungsi ekstremitas atas dan penglihatan) dan dengan tingkatan moderate (sedang) pada domain 1, 2, 4, 5, $6,8,9$, dan 12 (tenaga, peranan keluarga, mobilitas, suasana hati, kepribadian, pergaulan, pikiran, dan produktivitas). Diantara tingkat moderate pada
HRQoL, domain tenaga relatif yang paling rendah dengan rerata 2,63. Rerata skor kualitas hidup secara keseluruhan relatif lebih tinggi dijumpai pada domain fisik $(3,58 \pm 0,93)$ daripada domain psikososial $(3,21 \pm 0,73)$ dan rerata skor dari kualitas hidup pada laki-laki $(3,50 \pm 0,78)$ relatif lebih tinggi daripada perempuan $(3,13 \pm 0,83)$, baik dari rerata domain psikososial maupun fisik (Tabel 5).

\section{PEMBAHASAN}

Pada penelitian ini, hampir semua pasien pascastroke mengalami disfungsi seksual $(93,3 \%)$. Hal ini sesuai dengan penelitian Oyewole dkk tahun 2017 bahwa disfungsi seksual (DS) terjadi pada $87 \%$ pada pasien pascastroke. ${ }^{12}$ Angka penelitian ini jauh lebih tinggi dari pada penelitian lain. Hal ini dapat terjadi karena pasien yang datang ke poliklinik ingin memperoleh kesembuhan dari segala permasalahan terkait stroke, termasuk gangguan seksual, sehingga pasien lebih terbuka dan tidak malu mengungkapkannya. Berbeda pada penelitian sebelumnya di Nigeria, masalah seksual menjadi masalah yang sakral dan pribadi, serta tidak seharusnya dibahas terbuka dalam budaya setempat. Terutama di antara perempuan setempat, norma budaya melarang mereka mendiskusikan seks secara terbuka, bahkan sering dipandang sebagai tanda pergaulan bebas dan kecenderungan untuk perselingkuhan. ${ }^{12}$

Disfungsi seksual pada pasien pascastroke dapat terjadi oleh karena faktor organik maupun psikis. Pada pasien pascastroke dapat disebabkan oleh lesi struktural otak, pengaruh obat-obatan yang digunakan terutama obat antihipertensi (reserpine, penghambat saluran beta), antidepresan (terutama golong trisiklik), sedatif dan obat anti kejang (fenitoin, karbamazepin) juga karena pengaruh hormonal seperti testosterone dan androgen. ${ }^{22-23}$

Letak lesi pada hemisfer yang mengatur emosi juga dapat memengaruhi fungsi seksual seseorang. Letak lesi di hemisfer kanan dapat menyebabkan pasien melakukan tindakan impulsif sedangkan lesi di hemisfer kiri terutama bagian anterior dapat menyebabkan depresi berat yang mengakibatkan penurunan fungsi seksual sekunder. Kelemahan 
Tabel 5. Gambaran Kualitas Hidup yang Berhubungan dengan HRQoL ( $n=45)$

\begin{tabular}{clccc}
\hline Domain & Kualitas Hidup Spesifik Stroke & $\begin{array}{c}\text { Laki-laki } \\
(\mathbf{n}=\mathbf{3 4})\end{array}$ & $\begin{array}{c}\text { Perempuan } \\
(\mathbf{n}=\mathbf{1 1})\end{array}$ & $\begin{array}{c}\text { Keseluruhan } \\
(\mathbf{n}=\mathbf{4 5})\end{array}$ \\
\hline 1 & SSQoL tenaga & $3,38 \pm 1,00$ & $2,32 \pm 0,89$ & $2,63 \pm 1,09$ \\
2 & SSQoL peranan keluarga & $3,89 \pm 1,20$ & $2,70 \pm 0,97$ & $3,21 \pm 1,03$ \\
3 & SSQoL bahasa & $3,89 \pm 1,16$ & $4,40 \pm 1,44$ & $4,01 \pm 1,24$ \\
4 & SSQoL mobilitas & $3,29 \pm 1,16$ & $2,75 \pm 1,17$ & $3,16 \pm 1,17$ \\
5 & SSQoL suasana hati & $3,54 \pm 0,86$ & $3,10 \pm 0,90$ & $3,43 \pm 0,88$ \\
6 & SSQoL kepribadian & $3,04 \pm 1,19$ & $3,08 \pm 0,88$ & $3,06 \pm 1,11$ \\
7 & SSQoL merawat diri & $4,09 \pm 1,02$ & $3,16 \pm 1,33$ & $3,86 \pm 1,15$ \\
8 & SSQoL pergaulan & $3,25 \pm 0,85$ & $3,27 \pm 0,95$ & $3,26 \pm 0,86$ \\
9 & SSQoL pikiran & $3,59 \pm 1,48$ & $2,90 \pm 0,70$ & $3,42 \pm 1,36$ \\
10 & SSQoL fungsi ekstremitas atas & $3,80 \pm 0,91$ & $3,80 \pm 1,24$ & $3,68 \pm 1,01$ \\
11 & SSQoL penglihatan & $3,70 \pm 0,87$ & $3,80 \pm 1,18$ & $3,72 \pm 0,94$ \\
12 & SSQoL kerja/produktivitas & $3,58 \pm 1,21$ & $3,16 \pm 1,11$ & $3,48 \pm 1,19$ \\
& Domain psikososial & $3,29 \pm 0,77$ & $2,95 \pm 0,53$ & $3,21 \pm 0,73$ \\
& Domain fisik & $3,68 \pm 0,86$ & $3,27 \pm 1,09$ & $3,58 \pm 0,93$ \\
& Total skor SSQoL & $3,50 \pm 0,78$ & $3,13 \pm 0,83$ & $3,41 \pm 0,80$ \\
\hline
\end{tabular}

SSQoL: Stroke-Specific Quality of Life; HRQoL: Health-Related Quality of Life.

anggota tubuh yang terjadi pada pascastroke bisa juga ketidakmampuan dalam melakukan aktivitas seksual sehingga dapat menyebabkan penurunan frekuensi koitus. ${ }^{22-23}$

Proporsi kejadian DS pada laki-laki dan perempuan cukup tinggi pada penelitian ini dengan rerata usia subjek adalah 60 tahun $(60,27 \pm 0,12)$. Hal ini berdasarkan penelitian lain bahwa mayoritas pasien pascastroke mengalami disfungsi seksual dengan tingkatan yang bervariasi antara rerata umur subjek secara umum $(62,64 \pm 11,23)$ dengan rerata umur laki-laki $(62,98 \pm 11,34)$ dan perempuan $(62,26 \pm 11,19) .{ }^{12}$ Demikian pula laki-laki usia $>65$ tahun sudah mengalami penurunan libido dan hormon testosteron. ${ }^{24}$ Dampak fisik dan psikologis yang dialami pada usia tua dengan pascastroke cenderung lebih berat dibandingkan usia muda.

Skor fungsi seksual pada laki-laki relatif lebih tinggi daripada perempuan baik dari skala domain kesenangan, hasrat maupun gairah yang menunjukkan bahwa perempuan memiliki fungsi seksual yang relatif rendah secara keseluruhan. Disfungsi seksual pada perempuan secara umum berupa gangguan keinginan, gairah, orgasme, atau nyeri seksual.
Sebagian perempuan mengalami kelelahan dalam berpikir yang menurunkan kenikmatan seksual yang dapat menjadi gejala depresi reaktif. Tingginya angka kelelahan pada perempuan dapat mengakibatnya terjadi penghindaran hubungan seksual. ${ }^{8}$

Kelelahan merupakan hasil dari kombinasi lesi di otak secara organik dan penyesuaian psikososial pascastroke. Tinggi tingkat kelelahan di kalangan perempuan pascastroke dapat memperkuat penghindaran diri dari hubungan seksual. Walaupun kelelahan adalah luaran fisik dari stroke, hal itu bisa menyebabkan masalah psikologis yang menyebabkan perasaan rasa bersalah. Kelelahan menjadi faktor resiko dependen dari aktivitas kehidupan harian dan berkontribusi terhadap disfungsi seksual, baik langsung atau tidak langsung. ${ }^{10}$

Pada perempuan, keterbatasan fisik terkait partisipasi dalam tindakan seksual yang berfokus pada daerah genital tubuh wanita dipengaruhi oleh kelelahan. Keterbatasan yang diakibatkan oleh perubahan tubuh perempuan, ketakutan yang tidak jelas dan rasa takut mengalami stroke kembali, menyebabkan perempuan kehilangan rasa dalam hubungan aktivitas seksualnya. ${ }^{25}$ 
Kelelahan dapat menjadi luaran fisik pada stroke dan menyebabkan masalah psikologis. Hal ini kemungkinan juga dikaitkan perubahan peranan dan rasa bersalah yang dapat mengarah pada disfungsi seksual. Fungsi seksual pada perempuan memiliki proses yang lebih kompleks dibandingkan laki-laki dan lebih rentan terhadap faktor psikososial. Oleh karena itu, fungsi seksual relatif lebih tinggi laki-laki daripada perempuan. ${ }^{8}$

Pada penelitian ini, laki-laki lebih tinggi terjadi DS pascastroke dibandingkan pada perempuan, sejalan dengan jumlah insidensi stroke yang lebih tinggi pada laki-laki dan bahwa laki-laki berisiko mengalami stroke lebih tinggi dibanding perempuan. ${ }^{6,28}$ Hal ini dapat dihubungkan adanya faktor estrogen dan progesteron yang dominan pada perempuan yang berperan penting memberikan neuroprotektif stroke iskemik. ${ }^{26}$ Tingginya angka DS pada laki-laki dapat dikaitkan juga dengan nilai cut off instrumen penelitian ini yang lebih tinggi pada laki-laki (47) dibandingkan perempuan (41).

Defisit fisik pascastroke, seperti, hemiparesis/ hemiplegia dan/atau spastisitas dapat membatasi posisi dan gerakan tubuh yang dapat berkontribusi DS. Pasien pascastroke dengan anggota tubuh hemiparesis mungkin mengalami tantangan dalam merangkul, merangsang dan terlibat dalam hubungan seksual. Banyak gejala negatif dari spastisitas pascastroke, kelelahan, kelemahan anggota tubuh, dan hilangnya ketangkasan juga dapat menciptakan tantangan untuk kegiatan seksual. Air liur yang selalu keluar, pseudobulbar palsy, inkontinensia, dan gambaran tidak menarik lainnya dari pasien dapat menyebabkan masalah keintiman. ${ }^{8}$

Menurunnya frekuensi hubungan seksual berkorelasi positif dengan tingkat gangguan fisik dan tingkat ketergantungan pada aktivitas hidup harian. ${ }^{8}$ Fungsi motorik yang terbatas berkontribusi dalam keintiman aktivitas seksual bersama pasangan. Pada penelitian ini, kekuatan motorik secara spesifik tidak dimasukkan dalam status demografi, namun secara umum profil luaran fisik dikategorikan dalam bentuk tingkat disabilitas dan ketergantungan.

Pada penelitian ini, separuh subjek dalam keadaan mandiri (55\%) dan ketergantungan berat
(20\%), namun mayoritas subjek (93\%) mengalami DS. Hal ini bisa terjadi karena berbagai faktor. Penderita stroke tanpa cacat fisik ringan, hampir setengahnya mengalami penurunan libido, frekuensi koitus, gairah seksual, orgasme, dan kepuasan seksual. ${ }^{8}$ Hal ini dapat disebabkan faktor yang berkontribusi terhadap disfungsi seksual pasien pascastroke, seperti faktor psikososial (lama pernikahan, keengganan untuk aktivitas seksual, dan keyakinan akan stroke memengaruhi fungsi seksual) dan faktor klinis (usia, defisit fungsi fisik, dan faktor vaskular) yang dapat memengaruhi DS pada pascastroke. ${ }^{8,12}$

Kategori IB pada subjek penelitian ini terbanyak mandiri (55\%), sedangkan kategori disabilitas berdasarkan mRS tidak ada gejala disabilitas (disabilitas yang tidak signifikan). Hal ini sesuai dengan penelitian Asplund dkk yang dikutip dari Carod-Artal dkk tahun 2009 bahwa sekitar $50-70 \%$ pasien stroke yang bertahan memiliki kemandirian secara fungsional, tetapi $15-30 \%$ mengalami ketidakmampuan, dan 20\% membutuhkan perawatan di rumah sakit selama 3 bulan setelah onset. Hasil penelitian Stein dkk tahun 2013 memperlihatkan mayoritas pascastroke sebanyak $78,8 \%$ dengan kriteria tidak bergantung secara penuh..$^{9,11}$

Gambaran kualitas hidup yang berhubungan dengan kesehatan pada pasien pascastroke dengan menggunakan kuesioner SSQoL didapatkan hasil berupa skor total kualitas hidup yang berhubungan dengan kesehatan (HRQoL) pada subjek penelitian dengan tingkat sedang (moderate) dengan domain tenaga relatif paling rendah. Hal ini menunjukkan pasien pascastroke merasa lelah dalam performa aktivitas yang lama. Hal ini juga sesuai dengan penelitian Purba dkk tahun 2015 mengenai kualitas hidup pada pascastroke yang bertahan bahwa rerata domain kualitas hidup yang paling rendah adalah domain tenaga. ${ }^{16}$

Kelelahan yang dialami dapat disebabkan pasien pascastroke memiliki keterbatasan untuk melakukan kegiatan sehari-hari, sehingga pasien merasa lelah dalam performa di sebagian besar aktivitas mereka. Selain itu, sebagian besar subjek $(75,6 \%)$ adalah laki-laki, yang merasa tidak berharga 
karena persepsi sifat maskulin laki-laki adalah peran mereka sebagai penyedia dan pelindung bagi keluarga. Dengan demikian, kurangnya domain tenaga sebagai akibat berkurangnya kualitas hidup mereka.

Kualitas hidup secara keseluruhan pada subjek penelitian relatif lebih tinggi dijumpai pada domain fisik daripada domain psikososial. Hal ini sesuai dengan penelitian Oyewole dkk tahun 2017 bahwa pasien pascastroke memiliki skor kualitas hidup yang tinggi dan domain fisik lebih baik daripada domain psikososial. Domain psikososial HRQoL lebih terpengaruh daripada domain fisik di antara pascastroke yang bertahan. ${ }^{12}$ Ini menunjukkan bahwa meskipun gangguan motorik sering terjadi akibat stroke, emosional/psikologis jauh berdampak lebih besar.

Pada dasarnya, penelitian ini dengan penelitian Oyewole dkk, bahwa pasien pascastroke memiliki skor kualitas lebih tinggi pada domain fisik dibandingkan domain psikososial. Hal ini menunjukkan bahwa domain psikososial pada kualitas hidup lebih terkena dampak daripada domain psikis diantara pasien pascastroke. Disfungsi seksual dilaporkan berdampak negatif terhadap emosi dan kehidupan psikososial. ${ }^{12,16,27}$

Pada penelitian ini, kualitas hidup pada lakilaki relatif lebih tinggi daripada perempuan baik pada domain psikososial maupun domain fisik. Hal ini sesuai penelitian Hassa dkk skor kualitas hidup lebih rendah pada perempuan. Hal ini juga sesuai dengan Carot-Artal dkk bahwa perempuan memiliki kualitas hidup yang berhubungan dengan kesehatan secara keseluruhan yang lebih rendah. Rendahnya HRQoL pada perempuan adalah karena perempuan lebih sering memiliki kondisi kronis seperti artritis dan memiliki status sosioekonomi yang berbeda dibandingkan dengan laki-laki. Di samping itu perempuan memiliki perubahan yang lebih besar dalam peran keluarga pascastroke. Sebab lainnya antara lain usia perempuan yang lebih lama, prevalensi kecacatan yang lebih tinggi, dan gejala depresi yang lebih besar. ${ }^{28}$

Pada penelitian ini, suku paling banyak adalah suku Batak. Perempuan pada suku Batak memiliki kebiasaan bahwa perempuan juga berperan sebagai tulang punggung keluarga membantu suami dalam mencari nafkah. Bahkan perempuan suku Batak lebih banyak berperan di keluarga seperti berkebun, memanen, dan lain-lain, sedangkan laki-laki sedikit aktivitas. Oleh karena dampak psikosial pada perempuan cenderung lebih berat dan dapat berpengaruh pada kualitas hidup. Hal ini sejalan dengan penelitian bahwa perempuan pascastroke lebih banyak merasa depresi dan cemas juga merasakan kesakitan dan ketidaknyamanan serta menganggap mobilitasnya jadi lebih terbatas. Penelitian lain mengungkapkan bahwa perempuan pascastroke serangan pertama memiliki skor kualitas hidup yang lebih rendah, namun skornya meningkat pascaserangan kedua oleh karena perempuan memiliki kestabilan mental atau psikis dibandingkan laki-laki dalam beradaptasi menghadapi penyakit yang diderita. ${ }^{29}$

Penelitian ini memiliki beberapa kelemahan, antara lain kesulitan dalam mengindentifikasi secara jelas dan akurat riwayat disfungsi seksual yang dialami sudah dimiliki sebelum terjadinya stroke. Oleh karena informasi yang didapat hanya diperoleh dari anamnesis kepada subjek yang diteliti dan bersifat subjektif. Selain itu, penelitian ini bersifat deskriptif dan tidak menggambarkan hubungan antar variabel.

\section{KESIMPULAN}

Didapatkan prevalensi disfungsi seksual sebanyak $93,3 \%$ pada pasien pascastroke, terutama laki-laki. Berdasarkan penilaian disabilitasnya, mayoritas subjek pada keadaan mandiri dan disabilitas yang tidak signifikan. Gambaran kualitas hidup secara keseluruhan relatif lebih baik pada laki-laki dengan nilai yang berhubungan dengan kesehatan yang relatif paling rendah adalah domain tenaga.

\section{DAFTAR PUSTAKA}

1. Feigin VL, Forouzanfar MH, Krishnamurthi R, Mensah GA, Bennett DA, Moran AE, dkk From the global burden of disease study 2010. Lancet. 2014;383(9913):245-54.

2. Lahano AK, Chandio MA, Bhatti MI, Nawabshah SB. Frequency of common modifiable risk factors for 
stroke. GJMS. 2014;12(4).

3. Mendis S. Stroke disability and rehabilitation of stroke: World Health Organization perspective. Int J Stroke. 2013;8(1):3-4.

4. Yikilkan H, Gorpelioglu S, Basamakta B, Yikilkan H. Comorbid diseases and dyslipidemia among elderly home care stroke patients. Acta Medica. 2013;2:4852.

5. Benjamin EJ, Blaha MJ, Chiuve SE, Cushman M. Heart disease and stroke statistics-2017 update. Circulation. 2017;135(10):e146-603.

6. Kementrian Kesehatan Republik Indonesia. Lap Nas 2013. 2013. h. 1-384.

7. Rambe AS, Fitri FI. Correlation between the montreal cognitive assessment-indonesian version (MoCA-Ina) and the mini-mental state examination (MMSE) in elderly. Open Access Maced J Med Sci. 2017;5(7):915-9.

8. Park JH, Ovbiagele B, Feng W. Stroke and sexual dysfunction-a narrative review. J Neurol Sci . 2015;350(1-2):7-13.

9. Stein J, Hillinger M, Clancy C, Bishop L. Sexuality after stroke: patient counseling preferences. Disabil Rehabil. 2013;35(21):1842-7.

10. Park JH, Ovbiagele B, Feng W. Stroke and sexual dysfunction-a narrative review. J Neurol Sci. 2015;350(1-2):7-13.

11. Carod-Artal FJ, Egido JA. Quality of life after stroke: the importance of a good recovery. Cerebrovasc Dis. 2009;27:204-14.

12. Oyewole OO, Ogunlana MO, Gbiri CAO, Oritogun KS. Prevalence and impact of disability and sexual dysfunction on health-related quality of life of Nigerian stroke survivors. Disabil Rehabil. 2017;39(20):2081-6.

13. Cruz-Cruz C, Martinez-Nuñez JM, Perez ME, Kravzov-Jinich J, Ríos-Castañeda C, AltagraciaMartinez M. Evaluation of the stroke-specific qualityof-life (SSQOL) scale in mexico: a preliminary approach. Value Heal Reg Issues. 2013;2(3):392-7.

14. Rosenbaum T, Vadas D, Kalichman L. Sexual function in post-stroke patients. J Sex Med. 2014;11(1):15-21.

15. Goma SH, Marhan SA, Mahran DG, El-Hakeim EH, Ghandour AM. Multicenter assessment of healthrelated quality of life (HRQOL) among stroke survivors abstract. iMedPub Journals. 2016;7:96.

16. Purba WS, Amatayakul A, Wattanakul B. The relationship between depression, social support and quality of life of stroke survivors in Bukittinggi, Indonesia. J Health Res. 2015;29(1):S109-16.

17. Soertidewi L. Pemantauan dengan skala stroke. Dalam: Soertidewi L, Jannis J, editor. Stroke aspek diagnostik, patofisiologi, manajemen. Badan Penerbit FKUI; 2011. h. 301-15.

18. Pedersen SG, Heiberg GA, Nielsen JF, Friborg O, Stabel HH, Anke A, dkk. Validity, reliability and Norwegian adaptation of the stroke-specific quality of life (SS-QOL) scale. SAGE Open Med. 2018;6:110.

19. Garcia-Portilla MP, Saiz PA, Fonseca E, Al-Halabi S, Bobes-Bascaran MT, Arrojo M, dkk. Psychometric properties of the spanish version of the changes in sexual functioning questionnaire short-form (CSFQ$14)$ in patients with severe mental disorders. J Sex Med. 2011;8(5):1371-82.

20. Keller A, McGarvey EL, Clayton AH. Reliability and construct validity of the Changes in Sexual Functioning Questionnaire Short-Form (CSFQ-14). J Sex Marital Ther. 2006;32(1):43-52.

21. Hadiati D. Uji validitas dan reliabilitas stroke specific quality of life (SS-QOL) berbahasa Indonesia pada pasien stroke. Studi Ilmu Kedokteran Fisik dan Rehabilitasi FK Universitas Indonesia [tesis]. Jakarta: Universitas Indonesia; 2014.

22. Misbach J, Jannis J, Soertidewi L, Bustami M, Rasyid A, Francina S, dkk. Diagnosis stroke. Dalam: Soertidewi L, Jannis J, editor. Stroke aspek diagnostik, patofisiologi, manajemen. Jakarta: Badani Penerbit FKUI; 2011. h. 57-83.

23. Jannis J, Misbach J. Disfungsi seksual pada stroke. Dalam: Soertidewi L, Jannis J, editor. Stroke aspek diagnostik, patofisiologi, manajemen. Jakarta: Badan Penerbit FKUI; 2011. h. 217-38.

24. Cunningham GR, Stephens-Shields AJ, Rosen RC, Wang C, Bhasin S, Matsumoto AM, dkk. Testosterone treatment and sexual function in older men with low testosterone levels. J Clin Endocrinol Metab. 2016;101(8):3096-104.

25. Lever S, Pryor J. The impact of stroke on female sexuality. Disabil Rehabil. 2017;39(20):2011-20.

26. Kim TH, Vemuganti R. Effect of sex and age interactions on functional outcome after stroke. CNS Neurosci Ther. 2015;21(4):327-36.

27. Seymour LM, Wolf TJ. Participation changes in sexual functioning after mild stroke. OTJR Occup Particip Heal. 2014;34(2):72-80.

28. Oni OD, Aina OF, Olisah VO. Quality of life and associated factors among poststroke clinic attendees at a University Teaching Hospital in Nigeria. Niger Med J. 2016;57:290-8.

29. Hassa N, Hartono JEB, Pudjonarko D. Perbeadaan kualitas hidup berdasarkan short form-36 antara penderita stroke iskemik serangan pertama dengan kedua. Neurona. 2017;35(1):63-8. 